УДК 1.125

DOI https://doi.org/10.32837/apfs.v0i27.912

\author{
П. Д. Гуйван \\ ORCID ID: https://orcid.org/0000-0003-3058-4767 \\ кандидат юридичних наук, заслужений юрист України, \\ професор \\ Полтавського інституту бізнесу
}

\title{
ПРО КОНЦЕПЦІЮ ЧАСУ ЯК ПОСЛІДОВНІСТЬ ТА ЗМІНУ СТАНІВ ОБ’ЄКТА
}

Постановка проблеми. Однією з найактуальніших проблем часу є адекватний та правильний його вимір. Адже відповісти на питання, що таке час, це, власне, те ж, що визначитися із проблемою його вимірювання. В усякому разі саме в цьому полягає корінь, або сутність часу. Усвідомлення ролі, значення та основних функцій часу визначається в першу чергу не абсолютною точністю певної події в космічному масштабі, а такими чинниками, як прописані нормативно правила належної суспільної поведінки, правовими звичаями. Це тісно переплітається з індивідуальним особливостями людини: ступенем її свідомості та юридичної обізнаності, порядком сприйняття часового плину, зацікавленістю у дотриманні правил, характером діяльності. На зазначеній базі формується соціально визначений образ часу як мірила необхідних вчинків, належних та сприйнятних у правовій площині. Це дає змогу встановити нові темпоральні установки вчинення певних дій, спілкування особистостей, їхнього мислення. Саме в такий спосіб можливе ефективне вирішення завдання створення сприйняття та освоєння часу на особистісному рівні. При цьому необхідний інструментарій для з'ясування внутрішніх змін об'єктів, специфіки їх взаємодії в динаміці отримуємо саме внаслідок ретельного вивчення характеру окремих елементів суспільно значимих проявів у їхньому часовому перебігові.

Час традиційно розуміють як «атрибут», загальну форму буття матеріі, що проявляється у тривалості сущого та послідовності зміни станів усіх матеріальних систем і процесів у світі. Час то форма координації змін об’єктів та їхнього стану [1, с. 276]. А зміна явищ становить сутність часу [2, с. 400]. Утім, окремі події буття можуть періодично повторюватися, матерія може набувати попереднього стану протягом свого незворотного руху у часі. Відтак ритм відтворює повторюваність матеріальних процесів, забезпечує відносну стабільність та стійкість проявів природи. Тож його зміна (тобто збільшення чи зменшення проміжків часу між повторюваними явищами) в межах однієї системи відліку свідчить про зміну закономірності функціонування даного явища [3, с. 159, 161-162].

Аналіз останніх досліджень і публікацій. У науковій літературі дослідженням людиною об’єк- тивного часового плину та його зв'язку з явищами матеріального світу в тому числі щодо усвідомлення зміни станів розвитку юридично значимих для суспільства явищ присвятили увагу такі науковці, як Козирєв Н.А., Бергсон А., Солдатов А.В., Абасов А.С., Аскольдов С.А, Аскін Я.Ф., Вернадський В.І., Молчанов Ю.Б. та інші. У дослідженнях вчені постулювали, що часова сфера пізнання є якраз тією, повне охоплення та вивчення якої об'єктивно неможливе. Важливим продовжує залишатися питання вивчення співмірностей у перцепції таких станів реально наявних явищ, які охоплюються поняттями «сучасне», «минуле» та «майбутнє». Теоретичне співвідношення даних трьох часових суперпозицій завжди були одним iз актуальних аспектів, що гарантувало науковий інтерес у процесі сприйняття темпоральних властивостей. Зокрема, за однією 3 концепцій минуле, нинішне і майбутнє продукується сучасним періодом. Позаяк разом із процесом пізнання рухається і сам час, відтак явища взаємодії події в часі, співвідношення понять «сучасність», «минуле» і «майбутнє» постійно змінюється і відтак не можуть набути сталого характеру. Власне, доктрині наразі бракує аналізу ефективності та дієвості вивчення характеру співвідношення вказаних періодів, їхньої взаємодії з іншими природними явищами. Це має свої особистісні характеристики в частині сприйняття їх конкретними зовнішніми спостерігачами. Адже визначеність хоча б у методології досліджень значною мірою має значення для характеристики взаємин різних часових станів. Дослідження окремих підходів щодо ефективності подібної взаємодії, яка, зрештою, визначає сутність, квінтесенцію часу і може бути задане як єдність минулого. нинішнього та майбутнього, є метою цієї наукової статті.

Виклад основного матеріалу. Іще здавна дослідники питання темпорального опосередкування сущого переймалися окремими аспектами феноменальності часового усвідомлення характеру подій, їхнього розмежування на минулі, сучасні та майбутні. Свого часу подібні роздуми яскраво висловив Аврелій Авгутин: «Що ж таке час? Хто зміг би пояснити це просто і коротко? Хто зміг би осягнути подумки, щоб ясно про це розповісти? Про що, однак, згадуємо ми в розмові, як про зовсім звичне 
і знайоме, як не про час? I коли ми говоримо про нього, ми, звичайно, розуміємо, що це таке, і коли про нього говорить хтось інший, ми теж розуміємо його слова. Що ж таке час? Якщо ніхто мене про це не питає, я знаю, що таке час; якби я захотів пояснити запитувачу - ні, не знаю. Наполягаю, однак, на те, що твердо знаю: якби нічого не відбувалося, не було б минулого часу; якби ніщо не відбувалося, не було б майбутнього часу ... I якби даний момент завжди залишався справжнім і не йшов в минуле, то це був би вже не час, а вічність. Нинішнє виявляється охоплленим часом тільки тому, що вона йде в минуле» [4, с. 167]. Дійсно, можливість переходу минулого в сучасність, а в подальшому - в майбутнє, реалізує опцію істотного доповнення нашого емпіричного світу.

Час по-різному сприймався людьми упродовж перебігу століть. Циклічна зміна пір року, часу доби тощо асоціювалося з оборотом часових періодів по колу як проявом вічності часового ритму. Коли було винайдено засіб точного вимірювання часу шляхом певної фіксації його через однакові проміжки, то був важливий крок темпоральної визначеності. Наслідком даного відкриття став перехід в усвідомленні від циклічного його сприйняття до осмислення часового поступу як прямої лінії перебігу подій, що прямує від минулого до майбутнього через певні координати, які мають найменування сучасності. Це дозволило здійснити чітке розмежування категорій минулого та майбутнього, забезпечивши кожну з них відповідним набором атрибутивних ознак. Перейшовши від циклічного до лінійного прояву, час перестав усвідомлюватися як субстанція, підвладна людині. Адже початкові та кінцеві моменти часового перебігу набули невизначеного (безкінечного) характеру, що надало йому можливість перебігу незалежно від волі людей. Відтак люди почали розуміти, що вони не мають змоги впливати на об'єктивний сплив часу, а лише мусять йому підкорятися.

Існує філософська думка, згідно з якою не тільки властивості та стан об'єктів можуть мати вплив на час як характеристику матерії. У науці також напрацьована теорія, згідно з якою можливий і зворотній зв' язок: час як відносно самостійне явище, яке наділене власною енергією може проявляти вплив на певні процеси та об'єкти, що існують у природі [5, с. 30]. Такий вплив часу на властивості систем і процесів може бути виявлений лише опосередковано шляхом проведення дослідження всередині самих систем у темпоральному контексті. Дана теза була піддана серйозній критиці 3 боку дослідників матеріалістичного спрямування. Вони визначають час виключно як форму існування матеріï, яка, виходячи із сенсу матеріалізму, є проявом змісту, тобто самої матеpiï. Як наслідок, дані вчені категорично відкидають субстанціалізацію часу (тобто надання йому якостей особливої об’єктивної субстанції, об’єкта). Я.Ф. Аскін наводить низку обгрунтувань у підтвердження цієї позиції, використовуючи останні дослідження в галузі фізіології та геронтології. Так, зміни часової орієнтації, сприйняття людини під час набуття нею певних умовних рефлексів пояснюється не безпосереднім впливом часу, а дією інших об'єктивних зовнішніх факторів - подразників, що відбуваються в чітко встановлені моменти з урахуванням їх ритму, тривалості тощо. Іншими словами, організм реагує не на час, а на вплив певного матеріального середовища. Те ж саме відбувається під час старіння людського організму. Незважаючи на розхожий вираз «час старить», саме матеріальні процеси, що відбуваються з віком у клітинах людини, призводять до відповідних незворотних змін, а не безпосередній вплив часу [3, с. 61]. Утім, у фізиці все ж мають місце теоретичні формулювання, які, Ірунтуючись на наперед відомих здатностях простору і часу як вихідному матеріалі, встановлюють властивості самої матерії (теорема Ньотер ${ }^{1}$ ). I хоча тут слід враховувати теоретичний характер досліджень у даному напрямку, все ж не можна відкидати повністю тезу про взаємообумовленість часу та матеріального світу.

Особливим предметом наукового вивчення $€$ також питання про порядок зміни певних темпоральних станів певного явища. П. Ланжевен визначав час як сукупність подій, що слідують одне за одним у тій же точці простору, пов'язаній із даною системою відліку [6, с. 100]. Час є взаємодіючим триваючим процесом, спрямованим від минулого до майбутнього через нинішнє. При цьому остання категорія і є тією точкою відліку, від якої ми пізнаємо попередні чи наступні події. Окремі дослідники абсолютизують певні ланки цього ланцюжка. Так, А. Бергсон найбільш важливим вважає минуле, постулюючи час як безперервний прогрес минулого, що поїдає майбутнє і зростає, рухаючись уперед [7, с. 13]. М.0. Бердяєв теж зазначав, що майбутнє аж ніяк не може мати пріоритетного значення, оскільки історична дійсність перебуває в минулому, а без неї не було б нинішнього і не буде майбутнього [8, с. 409]. Інші вчені, навпаки, надавали більше значення майбутньому, в першу чергу виходячи з реальності та дієвості сучасного, позаяк для людини як соціального суб'єкта принциповою має бути новизна та наступні зміни [9, с. 96]. Утім, як би не виділялися окремі ланки даного темпорального ланцюга, мусимо ще раз підкреслити їх взаємопов'язаний характер. Послідовність процесів у часі якраз і забезпечується можливістю впливу нинішньої події на інші, які за таких обставин кваліфікуються як

\footnotetext{
1 Теоре́ма Еммі Ньотер доводить, що кожній безперерервній симетрії физичної системи відповідає певний закон збереження. Зокрема, закон збереження енергії відповідає однорідності часу.
} 
майбутні, та можливістю впливу на наявне зараз явище інших подій, що розглядаються як минулі [10, с. 39-46].

Реальна спрямованість часу від минулого до майбутнього проявляється, зокрема, в накопиченні пам'яті та знань про певні процеси та події, які відбулися в попередні періоди ${ }^{2}[11$, с. 202]. Отже, якщо оцінювати час як форму здійснення психічних процесів, то "початок», який можемо характеризувати як настання чогось саме зараз, пов'язаний із майбутнім, тоді як термін «закінчення» має зв'язок з минулим. Минуле вже здійснилося, вже має певний зміст, тому воно не може бути «початком», що не має конкретного вираження. У минулому особа почуває себе безсилою (його події вже нам не підвладні), в сьогоденні - володіє дієвою, але пов' язаною з усім минулим ініціативою, в майбутньому - вільним творцем, вказував I.М. Дьяков $[12$, с. 6]. Знаючи зовнішні прояви певного явища в минулий час або зараз, ми можемо розуміти, як вони виявляться в майбутньому. Таким чином, можливе передбачення наступних подій. Утім, $€$ певна відмінність такого передбачення майбутніх подій у класичній ньютонівській та сучасній фізичній теоріях. У першому випадку модель незалежності та абсолютності часу і простору, покладена на жорсткий принцип причинності, призводить до чіткої передбачуваності наступних подій. Зрештою це правило підтверджується емпірично і в розумних межах є досить дієвим у багатьох сферах людської діяльності протягом життя (інакше кажучи, у сферах макросвіту), коли швидкості значно менші швидкості світла. Натомість під час застосування реляційних парадигм майбутнє розглядається як суперпозиція всіх можливих варіантів, наступна реалізації яких може визначатися лише з певною вірогідністю і передбачення яких носить статистичний характер [13, с. 34-35]. Відтак тезу про передбачення наступних подій слід розуміти як вплив на них з урахуванням точності та достатності висхідних (нинішніх чи минулих) даних, 3 яких особа виходить під час конституювання своїх передбачень. Тобто з можливості передбачення окремих явищ в наступному періоді ще не витікає зумовленість майбутнього. Радше слід його оцінювати як творчі терени, інтелектуальний простір. Адже на відміну від минулого чи сучасного, які вже містять події, що вже відбулися чи відбуваються, майбутнє відкрите для творення.

Із внутрішньо притаманної часові властивості щодо його руху від минулого до майбутнього неодмінно витікає здатність часу забезпечувати причинно-наслідкову взаємодію. Нею визначається відмінність у часі між причиною та наслідком,

\footnotetext{
2 Зокрема, Стівен Хокінг, спрямованість часу від минулого до майбутнього характеризував поняттями так званих стріл часу. Однією з них - психологічною стрілою він визначав напрямок, в якому людина усвідомлює рух часу, що проявляєть ся в запам'ятовуванні тільки минулих подій, а не майбутніх.
}

яким би малим не був проміжок часу між цими чинниками, вони, безумовно, не можуть проявитися одночасно. Якщо користуватися теорією абсолютного часу, можна кваліфікувати як одночасні будь-які явища, що перебувають в одному й тому ж зрізі часового перебігу. Але в часі завжди є певні позиції, які можуть характеризуватися як «до чогось» чи «після чогось» .

Коли зафіксувати конкретний момент подій, всі інші явища по відношенню до них будуть по різні сторони такого зрізу: минуле - з одного боку, майбутнє - 3 іншого. Сьогодні дана конструкція зазнала певних коригувань з урахуванням релятивістського положення про те, що при одночасності між подіями відбуваються лиш просторові взаємини, тоді як відносини між ними у часі відсутні. Що ж стосується неодночасних подій, то, позаяк вони є продуктом системи часових та просторових взаємних впливів, їхній порядок та послідовність мають визначатися фізичними властивостями та взаємодіями. Отже, для встановлення такого порядку, тобто надання визначеності категоріям «раніше», «одночасно» та «пізніше»Ю потрібні якісь фізичні підстави, спираючись на які, вдалося б це зробити. Як такі підстави в науці було запропоновано використовувати відносини причинності, адже фізичні явища є елементами певної реальної чи можливої послідовності причинних взаємодій. Інакше кажучи, встановлення послідовності подій у часі, визначення взаємного порядку слідування категорій «минуле», «теперішнє» $\mathrm{i}$ «майбутнє» може бути досліджене через призму інструментарію причинної концепції. Більш того, окремі дослідники питання вважали теорію творчої причинності центральним елементом філософської системи, яка закладає фундамент нової філософсько-наукової картини світу [14, с. 85].

Сама постановка питання про онтологічну причинність викликана переконаністю свідомості, що все навколишнє чимось зумовлене, що за багатьма явищами, які ми спостерігаємо, ховаються сили, які з'єднали їх між собою, визначили їхній порядок та вклали в них реальність [15, с. 186-216]. Під причинністю в науці розуміється такі взаємини між об’єктами дослідження, коли декілька подій (як мінімум - дві) безпосередньо зумовлюють одна одну. Отже, знаючи про характер причинних відносин, можна обгрунтувати порядок явищ у часі. Такий підхід більш притаманний субстанціальній концепції, позаяк вона грунтується на принципах абсолютного і загального порядку у часі для усіх подій. Теорія відносності теж використовує засади причинності, не надаючи їм всеохоплюючого значення, враховуючи, в першу чергу, реальний вплив взаємопов'язаних об'єктів один на одного. Дійсно, якщо бути логічним, то той факт, що певна подія відбулася після іншої, ще не означає, що вона була зумовлена саме останньою. Тут наочно 
проявляється логічна помилка, викладена в постулаті post hoc, ergo propter hoc (після цього, значить, спричинено цим), яка полягає у прийнятті часової послідовності за причинну залежність. Такий підхід із певними припущеннями буде прийнятним у дослідженні категорії одночасності: якщо події відбуваються одночасно, між ними не може бути жодних причинних зв'язків. 3 іншого боку, безумовно, буде справедливою інша теза, яку коротко можна визначити як propter hoc, ergo post hoc (спричинено цим, значить, після цього). Дійсно, наявність причинного зв' язку між явищами чітко вказує на те, щозумовлююча подія настане раніше за обумовлену (буде встановлено порядок подій у часі). У принципі, можна погодитися 3 тезою прихильників релятивістської теорії, що концепція причинності все ж завузька для загального обгрунтування порядку та послідовності проявів матерії у часі, будь-яке явище породжується певною сукупністю факторів, і виділяти одні з них як «причини», а інші не розглядати в цій площині немає достатніх підстав [16, с. 132].

Той факт, що реальний вплив однієї події на іншу як першопричини можливий лише тоді, коли вона передує останній, приймається всіма дослідниками питання. Тож за таких обставин уже від наявності чи відсутності причинного зв'язку між різночасовими явищами залежить можливість конструювання взаємовідносин «минуле» - «нинішнє» - «майбутнє» або «раніше» - «одночасно» - «пізніше». Але в будь-якому разі порядок розташування даних категорій у часі матиме значення тільки для тих подій, між якими прослідковується конкретний причинний зв'язок.

Iз викладеного можемо дійти певних висновків. У науці, що вивчає темпоральні виміри сущого, існують питання про взаємне співставлення таких визначальних категорій, як час і буття. Але в більшості концепцій однією з головних ознак часу вважається його однонаправленість та незворотність. У прийнятому усвідомленні часовий перебіг завжди відбувається в напрямку від минулого до майбутнього. Цей рух проходить транзитом через сучасність, на зупиняючись у ній, і продовжується в майбутті, щоразу збільшуючи обсяг минулого а рахунок нових фактів, що відходять із сучасності в минулі події. При цьому обсяг минулих явищ об'єктивного світу, попри, здавалося б, їх ущільнення і додавання нових подій до їхнього складу, не зростає в силу фактичної безкінечності розміру даної темпоральної категорії.

\section{Jimepamypa}

1. Спиркин А.Г. Философия : учебник для технических вузов. Москва : Гардарики. 2000. 368 с.

2. Аскольдов С. Время онтологическое, психологическое и физическое. На переломе. Философские дискуссии 20-х годов. Москва : Политиздат, 1990.528 с.
3. Аскин Я.Ф. Проблема времени: ее философское истолкование. Москва : Мысль, 1966. 199 с.

4. Августин А. Исповедь. Абеляр П. История моих бедствий. Москва : Республика. 1992. 335 с.

5. Козырев Н.А. Причинная или несимметричная механика в линейном приближении. Пулково, 1958.88 с.

6. Новые идеи в математике : под ред. засл. проф. А.В. Васильева. сб. № 2. Пространство и время. I / Санкт-Петербург : Образование, 1913. 146 с.

7. Бергсон А. Творческая эволюция. Москва Санкт-Петербург, 1914. 307 с.

8. Бердяев Н.А. Время и вечность. На переломе. $\Phi u$ лософские дискуссии 20-х годов. Москва : Политиздат, 1990. C. 402-410.

9. Аскольдов С. Время и его преодоление. Мысль. 1922. № 3. С. 80-97.

10. Фейнман Р., Лейтон Р., Сэндс М. Фейнмановские лекции по физике (том 2). Пространство. Время. Движение. Москва : Из-во Мир, 1965. 164 с.

11. Хокинг С. Краткая история времени. От Большого Взрыва до черных дыр. Цет пч/Фкчкхжлики" 42220568 c.

12. Дьяков И.Н. Проблема взаимоотношения субстанции и времени. Москва : Этюд, 1917. Тип-я. им. А.И. Мамонтова. 42 с.

13. Абасов А.С. Пространство. Время. Познание. Баку, Элм, 1986. 122 с.

14. Громов А.В. Теория творческой причинности в философии Л.М. Лопатина : дисс. ... канд. филос. наук. Екатеринбург, 2006. 181 с.

15. Троицкий И. Анализ проблем онтологии в философском наследии Л.М. Лопатина. Христианское чтение. 2012. № 2. С. 186-216.

16. Молчанов Ю.Б. Четыре концепции времени в философии и физике. АН СССР, Институт философии. Москва : Наука. 1977. 192 с.

\section{Анотація}

Гуйван П. Д. Про концепцію часу як послідовність та зміну станів об'єкта. - Стаття.

Дана стаття присвячена дослідженню актуального питання про часовий елемент існування матерії. Позаяк час - то форма координації змін об'єктів та їхнього стану, важливим є наукове оформлення процесу пізнання темпоральної форми буття, що проявляється у тривалості сущого та послідовності зміни станів усіх матеріальних систем і процесів у світі. У роботі основна увага приділена вивченню співмірностей у перцепції таких станів реально наявних явищ, які охоплюються поняттями «сучасне», «минуле» та «майбутнє». Адже теоретичне співвідношення даних трьох часових суперпозицій завжди були одним із актуальних аспектів, що гарантувало науковий інтерес у процесі сприйняття темпоральних властивостей. Проаналізовано різні доктринальні підходи темпорального опосередкування сущого, що спрямовані на окремі аспекти феноменальності часового усвідомлення характеру подій, їх розмежування на минулі, сучасні та майбутні. Вивчена цікава філософська думка, згідно з якою не тільки властивості та стан об'єктів можуть мати вплив на час як характеристику матерії. За подібною тезою у природі можливий і зворотній зв'язок: час як відносно самостійне явище, яке наділене власною енергією, може 
проявляти вплив на певні процеси та об’єкти, що існують у природі. Також розглянута концепція противників цією теорії, які визначають час виключно як форму існування матерії, яка, виходячи із сенсу матеріалізму проявом змісту, тобто самої матерії. Як наслідок, дані вчені категорично відкидають субстанціалізацію часу, тобто надання йому якостей особливої об'єктивної субстанції, об'єкта. Також досліджене питання про порядок зміни певних темпоральних станів певного явища. Встановлено, що час є взаємодіючим триваючим процесом, спрямованим від минулого до майбутнього через нинішне. При цьому остання категорія і є тією точкою відліку, від якої ми пізнаємо попередні чи наступні подіi. Приділена увага властивості часу щодо його руху від минулого до майбутнього в порядку причинно-наслідкової взаємодії. У просторі завжди є певні позиції, які можуть характеризуватися як «до чогось» чи «після чогось». Якщо зафіксувати конкретний момент подій, всі інші явища по відношенню до них будуть по різні сторони такого зрізу: минуле - з одного боку, майбутне - з іншого.

Ключові слова: причинно-наслідковий зв'язок, темпоральні поняття «сучасне», «минуле» та «майбутнє» .

\section{Summary}

Guyvan P. D. About the concept of time as a sequence and change of states of an object. - Article.

This article is devoted to the study of the topical issue of the temporal element of the existence of matter. Since time is a form of coordination of changes in objects and their state, it is important to scientifically design the process of cognition of the temporal form of existence, which is manifested in the duration of existence and the sequence of changes in states of all material systems and processes in the world. The paper focuses on the study of proportions in the perception of such states of real phenomena, which are covered by the concepts of "present", "past" and "future". After all, the theoretical relationship of these three temporal superpositions has always been one of the relevant aspects, which guaranteed scientific interest in the process of perception of temporal properties. Various doctrinal approaches to the temporal mediation of being are analyzed, which are aimed at certain aspects of the phenomenality of temporal awareness of the nature of events, their delimitation into past, present and future. An interesting philosophical idea has been studied, according to which not only the properties and state of objects can influence time as a characteristic of matter. According to a similar thesis, feedback is possible in nature: time as a relatively independent phenomenon, endowed with its own energy, can influence certain processes and objects that exist in nature. Also considered is the concept of opponents of this theory, who define time exclusively as a form of existence of matter, which, based on the meaning of materialism, is nothing more than a manifestation of content, ie matter itself. As a result, these scientists categorically reject the substantialization of time, that is, giving it the qualities of a special objective substance, an object. The question of the order of change of certain temporal states of a certain phenomenon is also investigated. It has been established that time is an interacting ongoing process directed from the past to the future through the present. In this case, the last category is the starting point from which we learn previous or subsequent events. Attention is paid to the properties of time in relation to its movement from the past to the future in the order of causal interaction. There are always certain positions in space that can be characterized as "before something" or "after something". When you record a specific moment of events, all other phenomena in relation to them will be on different sides of this section: the past on the one hand, the future - on the other.

Key words: causal relationship, temporal concepts "present", "past" and "future". 